\title{
The contribution of cathedrals to psychological health and well-being: Assessing the impact of Cathedral Carol Services
}

\begin{tabular}{|c|c|}
\hline \multicolumn{2}{|c|}{$\begin{array}{l}\text { Authors: } \\
\text { Leslie J. Francis } \\
\text { Susan H. Jones } \\
\text { Ursula McKenna } \\
\text { Ur,4 }\end{array}$} \\
\hline \multicolumn{2}{|c|}{$\begin{array}{l}\text { Affiliations: } \\
{ }^{1} \text { Centre for Educational } \\
\text { Development, Appraisal and } \\
\text { Research (CEDAR), Faculty } \\
\text { of Social Sciences, University } \\
\text { of Warwick, Coventry, United } \\
\text { Kingdom }\end{array}$} \\
\hline \multicolumn{2}{|c|}{$\begin{array}{l}\text { Liverpool Cathedral, } \\
\text { Liverpool, United Kingdom }\end{array}$} \\
\hline \multicolumn{2}{|c|}{$\begin{array}{l}{ }^{3} \text { Department of Theology, } \\
\text { Bishop Grossesteste } \\
\text { University, Lincoln, United } \\
\text { Kingdom }\end{array}$} \\
\hline \multicolumn{2}{|c|}{$\begin{array}{l}{ }^{4} \text { Department of New } \\
\text { Testament Studies and } \\
\text { Related Literature, Facult } \\
\text { Theology and Religion, } \\
\text { University of Pretoria, } \\
\text { Pretoria, South Africa }\end{array}$} \\
\hline \multicolumn{2}{|c|}{$\begin{array}{l}\text { Description: } \\
\text { The authors are participating } \\
\text { as research fellows in the } \\
\text { project, 'Biblical Theology } \\
\text { and Hermeneutics', directed } \\
\text { by Prof. Dr Andries G. van } \\
\text { Aarde, Senior Research } \\
\text { Fellow in the Dean's Office at } \\
\text { the Faculty of Theology and } \\
\text { Religion of the University of } \\
\text { Pretoria, South Africa. }\end{array}$} \\
\hline \multicolumn{2}{|c|}{$\begin{array}{l}\text { Corresponding author: } \\
\text { Leslie Francis, } \\
\text { leslie.francis@warwick.ac.uk }\end{array}$} \\
\hline \multicolumn{2}{|c|}{$\begin{array}{l}\text { Dates: } \\
\text { Received: } 06 \text { May } 2021 \\
\text { Accepted: } 09 \text { Oct. } 2021 \\
\text { Published: } 02 \text { Dec. } 2021\end{array}$} \\
\hline \multicolumn{2}{|l|}{ Read online: } \\
\hline 回的回 & $\begin{array}{l}\text { Scan this QR } \\
\text { code with your } \\
\text { smart phone or } \\
\text { mobile device } \\
\text { to read online. }\end{array}$ \\
\hline
\end{tabular}

This study was designed to test the hypothesis that events such as the Christmas Eve Carol Services at Liverpool Cathedral that include some regular churchgoers (people who attend services most weeks) and much larger numbers of occasional visitors (who may attend church only once or twice a year) make a significant impact on the psychological health and wellbeing of the participants. Using a repeat-measure design, participants were invited to complete a copy of the Oxford Happiness Questionnaire while they were waiting for the service to begin and then to complete a second copy during a five-minute organ improvisation just before the close of the service. Data provided by 802 participants who completed both copies of the instrument demonstrated a significantly higher score on the Oxford Happiness Questionnaire at time two than at time one, suggesting that attendance at the service had exerted a positive impact on psychological health and well-being.

Contribution: Situated within the science of cathedral studies, this article demonstrates by means of a repeated-measure study that cathedrals can make a significant impact on the psychological health and well-being of the wider community served by them. The same wellbeing measure was completed by 802 participants at the Christmas Eve Carol Services before and after the event, with a significant increase in scores at time two.

Keywords: Cathedral studies; positive psychology; psychology of religion; Oxford Happiness Questionnaire; Christian; carol service.

\section{Introduction}

The Church of England remains the Established Church in England and retains a public commitment to serve the nation. This historic positioning continues to distinguish the Church of England from other Churches. The Church of England is not a denomination formed to serve its members. The Church of England is not a sect formed to separate its members from the secular society. The Church of England is a Church identified with the society in which it is located. There are three potentially distinguishing markers that may be publicly visible signs that distinguish the Church of England from neighbouring denominations or sects. These three signs are the parish structure, the provision of church schools and the ministry and mission of cathedrals.

The parish structure is at the very heart of the Church of England. Every community within England is linked to a parish church, and every parish church is served by a bishop whose pastoral oversight of that community is shared with an identifiable priest or group of priests. The parish church is open for all those who wish to call upon it. The parish priest is available for all those who wish to invite his or her attention (see Rumsey 2017; Walker 2014). In this sense, local people do not have to register their membership of the parish church. It is for those who do not wish such association to disassociate themselves from it, in the sense of asserting non-conformity. The contemporary centrality of the parish structure for the identity and future of the Church of England was unambiguously affirmed by Justin Welby, Archbishop of Canterbury, in an interview by Madeline Davies in the Church Times. Newly returning from a sabbatical, writing a book on reconciliation, Archbishop Welby said:

I assumed when I went to get ordained that I would spend my life in parish ministry. That is what I wanted to do, and I spent the first ten years of ordained life in parish ministry. I was a parish priest; as was

How to cite this article: Francis, L.J., Jones, S.H. \& McKenna, U., 2021, 'The contribution of cathedrals to psychological health and wellbeing: Assessing the impact of Cathedral Carol Services', HTS Teologiese Studies/Theological Studies 77(4), a6820. https://doi. org/10.4102/hts.v77i4.6820

Copyright: ๑ 2021. The Authors. Licensee: AOSIS. This work is licensed under the Creative Commons Attribution License. 
the Archbishop of York for much longer than I was. We are absolutely embedded in the parish. (Davies 2021:7)

\section{Anglican Church schools}

Church of England schools, supported within the statemaintained sector, provide an interesting example of the way in which the rationale for such historic provision has been clarified in light of increasing secularisation. Church of England schools have their origin in the founding of the National Society in 1811 with the intention of educating local children in accordance with the principles of the Established Church (Cruickshank 1963; Murphy 1971). The current integration of church schools within the state-maintained system was engineered by the 1944 Education Act (Dent 1947). Today one in four primary schools and one in 16 secondary schools in England are Church of England schools.

By the mid-1960s, there was growing pressure on the Church of England to justify its strong continuing presence in education. The Durham Report (1970) responded to that challenge under the chairmanship of Bishop Ian Ramsey. In this report, Ramsey crafted a clear philosophical distinction between the Church of England's twin objectives in maintaining church schools. The first objective was styled the Church's general aim of service to the nation. The second objective was styled the Church's domestic aim of service to the Church. The clear recommendation of the Durham Report was to prioritise the general aim above the domestic aim within an increasingly secular society.

Reflecting on the Durham Report 20 years after its publication, in an article entitled 'Theology of education', Francis (1990) suggested that those twin aims of the Church of England's involvement within the state-maintained system of education could be better nuanced within theological categories. Francis (1990) located the domestic aim identified by the Durham Report within a theology of nurture and recognised that the important function of church schools, engaging within the total mission of God's Church, was to do with the formation of Christian lives. Working together with Christian households and local congregations, church schools played a part in discipleship learning (see Astley 2015) and inherited the legacy of Jesus himself who shaped the 12 close disciples to walk in his footsteps.

Francis (1990) located the general aim identified by the Durham Report within a theology of service and recognised that this important function of church schools, again engaging within the total mission of God's Church, was to do with the service of the wider community. Working together with other statutory and voluntary provisions, church schools played a part within the wider provision and inherited the legacy of Jesus himself whose heart went out to the hungry crowd when he satisfied their hunger in the wilderness.

Reflecting further on the Durham Report, Francis (1990) added a third theological strand to the contemporary function of church schools within the state-maintained sector. Francis
(1990) styled this third strand a theology of prophecy. He argued that the very presence of church schools within the state-maintained system presented the Church of England with an opportunity and with a responsibility to speak within the public arena on educational matters, again inheriting the legacy of Jesus himself, whose prophetic voice in speaking out on behalf of the poor was authenticated by the visibility of his commitment to nurturing the 12 and to feeding the 5000 .

\section{Anglican cathedrals}

It is the contention of the present article that the theological work previously invested to clarify the nature of Anglican church schools can be extended to inform the theological rationale for Anglican cathedrals. Like church schools, Anglican cathedrals embrace the twin commitments expressed through theology of nurture (the formation of Christian disciples) and through theology of service (supporting and serving the wider community). Like church schools, the embodiment of Anglican cathedrals within their local communities presents the Church of England with an opportunity and with a responsibility to speak prophetically within the public arena on matters of local and national concern.

Although not expressed in the theological language of nurture and service, the Report of the Archbishops' Commission on Cathedrals (1994), Heritage and Renewal, made a strong case for Anglican cathedrals to distinguish between their two primary constituencies within 'the continuous stream of visitors and worshippers' (p. 3). In respect of the role of cathedrals among visitors, current reports on Anglican cathedrals highlight not only the continuing growth of visitor numbers but also the wider impact of these visitors on the local communities, with special attention given to the economic impact. For example, the Church of England's report, Cathedral statistics 2018, highlighted the finding that during 2018 cathedrals reported nearly 10 million visitors, an increase of over $10 \%$ on the previous year (Church of England 2019). Ecorys (2021), in the report to the Association of English Cathedrals, The economic and social impact of England's cathedrals, estimated over 9.5 million tourists or leisure visitors to cathedrals in 2019, an increase of 15\% over the total of 8.2 million estimated in 2014 by Ecorys (2014).

The report to the Association of English Cathedrals by Ecorys (2021) does not rest with calculating the impact of visitors on the local economy but proceeds to calculate the wider positive economic and social impact of cathedrals on the cities and communities that they serve. According to these calculations, in 2019, the 42 cathedrals in England contributed $£ 235$ million to their local economies, provided 6065 full-time equivalent jobs and 15,400 volunteering posts. The same report highlights the role of cathedrals in responding to local social needs, including running foodbanks, supporting groups for the vulnerable, for the unemployed and for the homeless and providing outreach activities in schools, residential homes and hospitals, lunch clubs, parent and toddler groups and community cafes. Economic value can be 
placed on all of these social interventions. It is precisely this level of economic impact within the local community that may leverage the prophetic voice of the cathedral in local affairs.

\section{More than economic impact}

While considerable attention has been given to documenting, emphasising and celebrating the hypothesised economic impact of Anglican cathedrals within local communities, less systematic research has been undertaken in conceptualising and assessing the psychological benefit on visitors and on participants at special events, in terms of psychological health and personal well-being.

Four studies concerned with cathedral visitors have probed the perceived impact of visiting these buildings. In their study of 814 visitors to four cathedrals in England (Coventry, Ely, Lichfield and Wells), Winter and Gasson (1996) reported that visitors identified the benefits of peace and quiet. In their study of 514 visitors to one cathedral in Wales (St Davids), Williams et al. (2007) also reported the central importance of a sense of peace. In their study of visitors to Canterbury Cathedral, Bond, Packer and Ballantyne (2015) reported five benefits experienced by visitors that they characterised as connecting spiritually and emotionally, as discovering new things, as engaging mentally, as a sense of interacting and belonging and as relaxing and finding peace. In their study of visitors to three different built environments (cathedral, castle and shopping centre), Ysseldyk, Haslam and Morton (2016) reported that for some people visiting the cathedral impacted their sense of self-esteem. Taken together, these four studies suggest that further work on assessing the psychological benefits of cathedrals to their visitors is worthwhile.

Alongside the general business of welcoming visitors into the building, there are occasions within the year when cathedrals welcome visitors to engage with their wider provision of worship on special occasions. Among such special occasions, the event that has received the most attention by researchers is the Christmas carol service, from both a qualitative perspective (Coleman, Bowman \& Sepp 2019; Murphy 2016; Muskett 2017; Phillips 2010) and a quantitative perspective (Francis, Edwards \& ap Siôn 2021; Walker 2012a, 2012b, 2013, 2015a, 2015b). Within this context, Francis et al. (2020) invited participants to assess the impact of attending the service on their spiritual well-being, using the model of spiritual well-being proposed by Fisher (2004, 2010, 2011, 2016, 2021). Fisher's model conceptualises spiritual health in relational terms across four domains that he characterises as: the personal domain, how people relate to themselves; the communal domain, how people relate to others; the environmental domain, how people relate to the world; and the transcendental domain, how people relate to God or to ultimate values. Drawing on data provided by 420 participants attending a pre-Christmas carol service in Liverpool Cathedral, Francis et al. (2020) reported that these participants had perceived the service as helping them over all four domains: $66 \%$ felt better about themselves (personal domain), 64\% felt better about their relationship with other people (communal domain), 54\% felt better about their relationship with the world (environmental domain) and $56 \%$ felt better about their relationship with God (transcendental domain). The quantitative findings reported by Francis et al. (2020) were amplified and complemented by a qualitative analysis of the comments written on the back page of the questionnaire. From his analysis of these comments, Pike (2021:9) concluded that 'the cathedral and its liturgy served as a centre of catharsis from which the participants came away feeling refreshed, profoundly moved and with improved spirits'. These studies suggest that further work on assessing the psychological benefit of cathedrals to those who participate in special services is worthwhile.

\section{Seeking a more rigorous approach}

The studies reviewed above were concerned with evaluating the psychological benefit of cathedrals, either on visitors or on participants at special services, which have relied on selfreported perceptions. Francis and Jones (2020) proposed a scientifically more rigorous way through which to assess the psychological effects of attendance at a cathedral carol service. They suggested measuring the psychological wellbeing of participants at two points: first when they arrived and before the service started and second towards the end of the service and before they went home. They suggested reconceptualising the service as an intervention deliberately positioned within the lives of the participants and attempting to gauge the impact of this intervention by means of a classic test-retest study. The present article builds on that earlier study by Francis and Jones (2020) and does so by locating the research within a wider discussion of the conceptualisation and measurement of psychological health and well-being.

The notions of psychological health and well-being reside at the heart of the field of positive psychology. Yet within this field, there is considerable debate regarding the conceptualisation and measurement of psychological health and well-being (Gallagher \& Lopez 2019). What precisely it is that is being measured remains crucial for the interpretation and generalisation of the findings. Within the range of constructs considered by positive psychology, the notion of happiness emerged as of particular significance at the beginning of the 21st century (Argyle 2001; Csikszentmihalyi 2002; Lyubomirsky, Sheldon \& Schkade 2005; Ryan \& Deci 2001; Seligman 2002). The notion of happiness has also attracted particular attention at the same time within the developing field of the positive psychology of religion (Francis, Jones \& Wilcox 2000; Robbins \& Francis 1996).

In order to establish a coherent network of research designed to map the association between religion and happiness, Robbins and Francis (1996) and Francis et al. (2000) proposed coordinating disparate studies through agreement on the consistent use of a common measure. For this purpose, they argued that such a programme of research could be integrated by adopting the conceptualisation of happiness proposed by Argyle and Crossland (1987) and Argyle, Martin and 
Crossland (1989) and operationalised in the Oxford Happiness Inventory. They commended this instrument for robust conceptualisation, sound operationalisation and a growing body of empirical studies from which an integrated tapestry of findings could be constructed.

The operationalisation of happiness proposed by Argyle and Crossland (1987) and Argyle et al. (1989) embraced three components of the construct: the frequency and degree of positive affect or joy; the average level of satisfaction over a period and the absence of negative feelings, such as depression and anxiety. Working from this definition, they initially developed the Oxford Happiness Inventory for which they reported internal reliability of .90 using alpha (Cronbach 1951) and a 7-week test-retest reliability of .78. Construct validity was established against recognised measures of the three hypothesised components of happiness, showing correlations of .32 with the positive affect scale of the Bradburn Balance Affect measure (Bradburn 1969), -.52 with the Beck Depression Inventory (Beck et al. 1961) and .57 with Argyle's own life satisfaction index. The conceptualisation and operationalisation of happiness offer broad coverage of subjective well-being, embracing as Kashdan (2004) observes, the notions of aesthetic appreciation, autonomy, humour, kindness, physical health, self-efficacy, self-esteem, sense of purpose and social interest.

In its operationalised form, the Oxford Happiness Inventory comprises a set of 29 multiple-choice items for each of which participants were offered four options designed to reflect incremental levels of happiness, for example, I do not feel happy, I feel fairly happy, I am very happy and I am incredibly happy. An instrument of this nature was relatively straightforward to administer as part of a battery of tests, but also somewhat bulky. It is for these reasons that Hills and Argyle (2002) subsequently proposed the more compact Oxford Happiness Questionnaire that comprised a set of 29 Likert scale items, originally rated on a six-point scale and subsequently on the conventional five-point scale. In their foundation article, Hills and Argyle (2002) reported a high correlation between the two instruments $(r=.80)$. The two instruments were also shown to be correlated in highly similar ways with a battery of personality variables known to be associated with wellbeing. Another variant, the Oxford Happiness Measure has also been introduced into the literature (Elken, Francis \& Robbins 2010).

Another attraction of the Oxford Happiness Inventory and the related family of measures is the way in which the English language original form quickly became translated and accessible in a range of languages, including Arabic (AbdelKhalek 2005), Chinese (Lu et al. 1997), Dutch (Janssen et al. 2006), German (Lewis, Francis \& Ziebertz 2002), Hebrew (Francis \& Katz 2000), Hindi (Arunachalan 2019), Italian (Meleddu et al. 2012), Japanese (Furnham \& Cheng 1999), Persian (Bayani 2008), Portugese (Neto 2001) and Turkish (Doğan \& Çötok 2011).
The Oxford Happiness Inventory and the related family of measures have now been used in a series of correlational studies designed to explore the association between religion and positive psychology within Christian (Francis et al. 2000; Francis \& Lester 1997; Francis \& Lewis 2016; Francis \& Robbins 2000; Francis, Robbins \& White 2003; Robbins \& Francis 1996), Hindu (Tiliopoulos, Francis \& Slatter 2011), Islamic (Francis, Ok \& Robbins 2017; Tekke, Francis \& Robbins 2018) and Jewish (Francis et al. 2004; Francis \& Katz 2002; Francis, Yablon \& Robbins 2014) contexts. All these studies recorded a positive significant correlation between religion and happiness as measured by the Oxford Happiness Inventory family of measure.

Building on this established research tradition, Francis and Jones (2020) moved beyond correlational studies to examine whether attendance at a religious service impacts the participants' experience of happiness as conceptualised and operationalised by the Oxford Happiness Inventory family of measure. This initial attempt to apply a test-retest study was conducted among participants at the Holly Bough Service held in Liverpool Cathedral on the Fourth Sunday of Advent 2019. This is a service that attracts a wide range of participants, including regular churchgoers (who attend services somewhere most weeks) and occasional visitors to places of worship (sometimes annual). A total of 383 participants completed one copy of the Oxford Happiness Questionnaire while they were waiting for the service to begin and a second copy during a 5-min organ improvisation just before the close of the service. The data demonstrated a significant increase in happiness scores at time two over time one, suggesting that participation in the Holly Bough Service was reflected in a higher sense of happiness.

The earlier phase of correlational studies initiated by Robbins and Francis (1996) and Francis et al. (2000) designed to map the association between religion and happiness using the Oxford Happiness Inventory argued that secure foundations within the positive psychology of religion needed to be created by patient replication studies among different populations and in different contexts. The current phase of repeated-measure studies within the science of cathedral studies requires similar patient replication. Against this background, the aim of the present study is to repeat the research design employed on the evening of the Fourth Sunday of Advent 2019, during the Holly Bough Service in Liverpool Cathedral and to do so in the same location at the two Carol Services held during the afternoon of Christmas Eve 2019. The experiences of the Holly Bough Service and the Carol Services differ in two key ways. The Holly Bough Service belongs to the mood of the liturgical season of Advent, while the Carol Services already anticipate the mood of Christian celebration. The Holly Bough Service held in the evening is less likely to attract families and children than the Carol Services held in the afternoon.

\section{Method Procedure}

When people came to Liverpool Cathedral for the Christmas Eve Carol Services, the welcomers gave them a copy of the 
service and a white envelope containing the questionnaire and a pen. The welcomers invited participants to complete the questionnaire. This invitation was reinforced by the video screens organised around the cathedral to relay the service. The front page of the questionnaire carried the following message from the Dean:

As Dean of this wonderful cathedral I would like to listen to and to learn from the many people who come to our special services preparing for Christmas. By listening and learning I hope to be able to plan wisely for the future.

This survey has been designed with two parts. I would like to invite you to complete part one while you are sitting and waiting for the service to begin. Then toward the end of the service there will be an opportunity for you to complete part two.

Everything you tell us is completely confidential and anonymous. Please feel free to answer as honestly as you can. We want to find out what people are really feeling and thinking about what we are doing as a Cathedral.

Please finish completing the questionnaire before you go, and leave the questionnaire on your seat.

Thank you for your help and cooperation.

\section{Instrument}

The questionnaire comprised two parts: Part one, completed while waiting for the service to start, explored demographic, background and religious factors and included both the Oxford Happiness Questionnaire (Hills \& Argyle 2002) and the Francis Psychological Type and Emotional Temperament Scales (Francis 2005). Part two, completed towards the end of the service during an organ improvisation, explored perceptions of the service and the second presentation of the Oxford Happiness Questionnaire.

The Oxford Happiness Questionnaire as proposed by Hills and Argyle (2002) comprises 29 items, 17 with positive valency and 12 with negative valency. Examples of the positive items include: I feel like life is very rewarding; I am always committed and involved; I feel able to take anything on. Examples of negative items include: I am not particularly optimistic about the future; I don't feel particularly pleased with the way I am; I feel that I am not especially in control of my life. While originally developed for rating on a six-point scale, current usage has reverted to the conventional fivepoint Likert rating: agree strongly (5), agree (4), not certain (3), disagree (2) and disagree strongly (1). In the foundation article, Hills and Argyle (2002) reported a high level of internal consistency reliability in terms of the alpha coefficient (Cronbach 1951): $\alpha=.91$. In the first presentation of the Oxford Happiness Questionnaire (before the service began), participants were invited to rate each of the 29 items in respect of the prompt, 'How I have felt over the past week about $\mathrm{me}^{\prime}$. In the second presentation of the Oxford Happiness Questionnaire (during the organ improvisation on 'In the bleak midwinter'), the participants were invited to rate each of the 29 items in respect of the prompt, 'How I am feeling about me now'.

\section{Participants}

A total of 802 participants at the Christmas Eve Carol Services completed the Oxford Happiness Questionnaire both at time one and time two. These 802 participants comprised 284 males and 495 females and 23 individuals preferred not to say: 43 were under the age of 20 years, 92 in their 20s, 106 in their 30s, 136 in their 40s, 186 in their 50s, 171 in their 60s, 59 in their 70s, six were aged 80 years or over and three preferred not to say. The majority described their present or most recent work as professional or semi-professional (80\%), $10 \%$ as manual, $7 \%$ as student and the remaining $4 \%$ preferred not to say. In terms of religious identity, $81 \%$ described themselves as Christian, $17 \%$ as none, $1 \%$ as either Buddhist, Hindu or Jewish and 1\% preferred not to say. The $81 \%$ who described themselves as Christian comprised 49\% Anglican, 18\% Catholic, 3\% Methodist and 2\% Pentecostal. The remaining 9\% included a few Orthodox, Presbyterian, Baptist, Unitarian and other unspecified. In terms of attendance at acts of public worship (apart from occasions such as weddings and funerals), 18\% of the 802 participants reported weekly attendance, $6 \%$ at least once a month, $14 \%$ at least six times a year, $44 \%$ at least once a year, $18 \%$ never and $1 \%$ preferred not to say.

\section{Analysis}

The data were analysed by SPSS employing the frequency, reliability and $t$-test routines.

\section{Results}

The first step in data analysis concerned an examination of the psychometric properties of the Oxford Happiness Questionnaire in terms of the alpha coefficient (Cronbach 1951) as an index of internal consistency reliability, the correlations between the individual items and the sum of the other 28 items as a measure of the contribution of each item towards the homogeneity of the scale and the item endorsement (presented as the sum of the agree and agree strongly responses) as an index of the variability in item discrimination. The data presented in Table 1 demonstrate a high level of internal consistency reliability $(\alpha=.89)$. The majority of items correlated well with the total of the remaining items but with sufficient variability to reflect the width of the construct being accessed. The item discrimination varies between $37 \%$ and $94 \%$ for the positive items and between $9 \%$ and $51 \%$ for the negative items, demonstrating a wide and helpful range. On the second administration, similar results were reported with an alpha coefficient of .92 .

The second step in data analyses employed the $t$-test to examine the statistical significance of the difference between scores recorded on the two occasions. The data presented in Table 2 demonstrate a significant increase at the .001 level of probability from a mean score of 103.3 at time one to a mean score of 105.3 at time two.

\section{Discussion and conclusion}

The present study was located in two research fields, the positive psychology of religion (Francis et al. 2000) and the 
TABLE 1: Oxford Happiness Questionnaire: Scale properties.

\begin{tabular}{|c|c|c|}
\hline Questionnaire items & $r$ & $\%$ \\
\hline $\begin{array}{l}\text { I do not feel particularly pleased with the way } \\
\text { I am* }\end{array}$ & .43 & 28 \\
\hline I am intensely interested in other people & .14 & 66 \\
\hline I feel that life is very rewarding & .62 & 79 \\
\hline $\begin{array}{l}\text { I have very warm feelings towards almost } \\
\text { everyone }\end{array}$ & .37 & 63 \\
\hline I rarely wake up feeling rested* & .33 & 35 \\
\hline I am not particularly optimistic about the future* & .47 & 24 \\
\hline I find most things amusing & .29 & 50 \\
\hline I am always committed and involved & .42 & 68 \\
\hline Life is good & .64 & 84 \\
\hline I do not think that the world is a good place* & .34 & 36 \\
\hline I laugh a lot & .52 & 79 \\
\hline I am well satisfied about everything in my life & .60 & 59 \\
\hline I do not think I look attractive* & .41 & 20 \\
\hline $\begin{array}{l}\text { There is a gap between what I would like to do } \\
\text { and what I have done* }\end{array}$ & .45 & 51 \\
\hline I am very happy & .67 & 71 \\
\hline I find beauty in some things & .24 & 94 \\
\hline I always have a cheerful effect on others & .46 & 59 \\
\hline I can fit in everything I want to & .34 & 37 \\
\hline I feel that I am not especially in control of my life* & .52 & 27 \\
\hline I feel able to take anything on & .51 & 51 \\
\hline I feel fully mentally alert & .54 & 69 \\
\hline I often experience joy and elation & .60 & 75 \\
\hline I do not find it easy to make decisions* & .42 & 31 \\
\hline $\begin{array}{l}\text { I do not have a particular sense of meaning and } \\
\text { purpose in my life* }\end{array}$ & .58 & 18 \\
\hline I feel I have a great deal of energy & .55 & 50 \\
\hline I usually have a good influence on events & .44 & 62 \\
\hline I do not have fun with other people* & .46 & 9 \\
\hline I do not feel particularly healthy* & .49 & 20 \\
\hline $\begin{array}{l}\text { I do not have particularly happy memories of the } \\
\text { past* }\end{array}$ & .35 & 16 \\
\hline Alpha & .89 & - \\
\hline
\end{tabular}

Note: $r$, correlation between individual item and the sum of the other items.

$\%$, percentage of agree and agree strongly responses.

$*$, these items are reverse coded to compute $r$ but not $\%$

science of cathedral studies (Francis 2015). Within the positive psychology of religion, a series of studies initiated by Robbins and Francis (1996) had systematically explored the connection between religion and happiness, as conceptualised and operationalised by the Oxford Happiness Inventory family of measures, employing correlational techniques. These studies, conducted within Christian, Hindu, Islamic and Jewish contexts, had consistently shown a positive correlation between religion and happiness, understood within positive psychology to function as an indicator of psychological health and well-being. The key scientific principle underpinning this programme of research was that of careful replication and extension to construct a secure interconnected body of knowledge.

Within cathedral studies, Francis and Jones (2020) had invited participants at the Holy Bough Service held in Liverpool Cathedral on the Fourth Sunday of Advent 2019 to complete copies of the Oxford Happiness Questionnaire both while waiting for the service to begin and again during an organ interlude close to the end of the service. Data provided by 383 participants who had completed both copies of the instrument demonstrated a significantly higher score on the
TABLE 2: Change over time.

\begin{tabular}{lccccc}
\hline Time & $\boldsymbol{N}$ & Mean & $\boldsymbol{S D}$ & $\boldsymbol{T}$ & $\boldsymbol{p}<$ \\
\hline Time 1 & 802 & 103.3 & 13.9 & - & - \\
Time 2 & 802 & 105.3 & 14.6 & 7.88 & .001 \\
\hline
\end{tabular}

Oxford Happiness Questionnaire at time two than at time one, suggesting that attendance at the service had exerted a positive impact on psychological health and well-being. In the scientific spirit of replication, the present study replicated the repeated-measure design initiated by Francis and Jones (2020) on a different occasion at the same Cathedral, during the two afternoon Carol Services held on Christmas Eve 2019. Data provided by 802 participants on this occasion confirmed the findings from the earlier study. Two main conclusions follow from these findings.

The first conclusion concerns the contribution to knowledge made within the field of the positive psychology of religion. The present study, together with the earlier work reported by Francis and Jones (2020) offered a fresh perspective on the connection between religious attendance and psychological health and well-being. Alongside the tradition of correlational studies that demonstrate the association between religion and happiness (but offer little information about the directionality of that association), the repeated-measure studies demonstrate the impact of religious attendance on the recorded level of happiness amongs participants. Taking seriously the three components of the conceptualisation of happiness underpinning the Oxford Happiness Inventory family of measure, these data suggest that religious attendance is reflected in a changed perception of the frequency and degree of positive affect or joy, the average level of satisfaction over a period of time and the absence of negative feelings, such as depression and anxiety.

The second conclusion concerns the contribution to knowledge made within the field of the science of cathedral studies. The present study, together with the earlier work reported by Francis and Jones (2020), offers a fresh perspective on the contribution made by cathedrals to the wider communities within which they are located. Together these two studies have quantified the impact that attendance at major events such as the Holly Bough Service and the Christmas Eve Carol Services has on those who attend. The limitation associated with the repeated-measure design employed within these studies is that it offers no insight into the lasting endurance of this beneficial effect. Such impact as has been demonstrated, however, comes at a considerable cost. The foundation of Liverpool Cathedral, for example, maintains the largest cathedral in England, the fifth largest in Europe and the seventh largest in the world. Designed by Giles Gilbert Scott as a fine example of the development of modern Gothic architecture, Liverpool Cathedral was consecrated in 1924 long before its completion in 1978 (see further Kennerley 2008; Thomas 2018). The building itself plays an important role in creating the environment for an encounter with those who attend services there. The foundation of Liverpool Cathedral 
maintains a highly skilled body of clergy, professional musicians and lay personnel who jointly effect what Bishop David Walker (2012b:993) styles 'performance with very high production values'. Here a religious foundation stewards resources that, as the present research demonstrates, serve wider public benefit within the city and the surrounding area.

The idea of employing repeated-measure studies within the science of cathedral studies remains novel. The two extant studies have both focused on the same location (Liverpool Cathedral) and at the same time of year (Christmas). In the spirit of scientific replication, these two studies need further replication and development in other locations and within other types of events and services.

\section{Acknowledgements Competing interests}

The authors declare that they have no financial or personal relationships that may have inappropriately influenced them in writing this article.

\section{Authors' contributions}

L.J.F. took responsibility for the overall conceptualisation of the article. S.J. oversaw the involvement of the cathedral in the project and the design of the survey instrument. U.M. curated the data and gave oversight to the data analysis. All authors contributed to the writing and agreed with the final text.

\section{Ethical considerations}

Ethical clearance to conduct this study was obtained from St. Mary's Centre Ethics Committee (No. SMC19EC0011).

\section{Funding information}

This research received no specific grant from any funding agency in the public, commercial or not-for-profit sectors.

\section{Data availability}

Data are available from the first author upon reasonable request.

\section{Disclaimer}

The views and opinions expressed in this article are those of the authors and do not necessarily reflect the official policy or position of any affiliated agency of the authors.

\section{References}

Abdel-Khalek, A.M., 2005, 'Quality of life, subjective wellbeing, and religiosity in Muslim college students', Quality of Life Research 19, 1133-1143. https://doi. org/10.1007/s11136-010-9676-7

Archbishops' Commission on Cathedrals, 1994, Heritage and renewal, Church House Publishing, London.

Argyle, M., 2001, The psychology of happiness, 2nd edn., Routledge, New York, NY.
Argyle, M. \& Crossland, J., 1987, 'Dimensions of positive emotions', British Journal of Social Psychology 26(2), 127-137. https://doi.org/10.1111/j.2044-8309.1987.tb00773.x

Argyle, M., Martin, M. \& Crossland, J., 1989, 'Happiness as a function of personality and social encounters', in J.P. Forgas \& J.M. Innes (eds.), Recent advances in socia psychology: An international perspective, pp. 189-203, Elsevier Science Publishers, Amsterdam.

Arunachalan, T., 2019, 'An investigation on the factor structure of the Hindi version of Oxford Happiness Questionnaire (OHQ)', Universitas Psychologia 18(1), 1-11. https://doi.org/10.11144/Javeriana.upsy18-1.ifsh

Astley, J., 2015, 'Forming disciples: Some educational and biblical reflections', Rural Theology 13(1), 4-17. https://doi.org/10.1179/1470499415Z.00000000037

Bayani, A.A., 2008, 'Test-retest reliability, internal consistency, and construct validity of the Farsi version of the Oxford Happiness Inventory', Psychological Reports 103 , 139-144. https://doi.org/10.2466/pr0.103.5.139-144

Beck, T., Ward, C.H., Mendelson, M., Hock, J. \& Erbaugh, J., 1961, 'An inventory for measuring depression', Archives of General Psychiatry 7, 158-216. https://doi. org/10.1001/archpsyc.1961.01710120031004

Bond, N., Packer, J. \& Ballantyne, R., 2015, 'Exploring visitor experiences, activities and benefits at three religious tourism sites', International Journal of Tourism Research 17(5), 471-481. https://doi.org/10.1002/jtr.2014

Bradburn, N.M., 1969, The structure of psychological well-being, Aldine, Chicago, IL.

Church of England, 2019, Cathedral statistics 2018, Church of England, London.

Coleman, S., Bowman, M. \& Sepp, T., 2019, 'A cathedral is not just for Christmas. Civic Christianity in the multicultural city', in P.E. Klassen \& M. Scheer (eds.), The public work of Christmas: Difference and belonging in multicultural societies, pp. 240-261, McGill-Queen's University Press, Montreal \& Kingston.

Cronbach, L.J., 1951, 'Coefficient alpha and the internal structure of tests', Psychometrika 16, 297-334. https://doi.org/10.1007/BF02310555

Cruickshank, M., 1963, Church and state in English education, Macmillan, London.

Csikszentmihalyi, M., 2002, Flow: The classic work on how to achieve happiness, Random House, New York, NY.

Davies, M., 2021, 'Archbishop Welby talks to Madeline Davies about reform and the pandemic', Church Times 8270, 7-8.

Dent, H.C., 1947, The Education Act 1944: Provisions, possibilities and some problems, 3rd edn., University of London Press, London.

Doğan, T. \& Çötok, N.A., 2011, 'Adaptation of the short form of the Oxford Happiness Questionnaire into Turkish: A validity and reliability study', Journal of Turkish Psychological Counselling and Guidance 4, 165-172.

Durham Report, 1970, The fourth $R$ : The report of the commission on religious education in schools, National Society and SPCK, London.

Ecorys, 2014, The economic and social impacts of England's cathedrals, viewed 21 September 2021, from https://www.englishcathedrals.co.uk/wp-content/ uploads/2021/05/economic-social-impacts-englands-cathedrals-2.pdf.

Ecorys, 2021, The economic and social impacts of England's cathedrals, viewed 21 September 2021, from https://www.englishcathedrals.co.uk/wp-content/ uploads/2021/08/Economic-Social-Impacts-of-Englands-Cathedrals-CaseStudies-2019.pdf.

Elken, A., Francis, L.J. \& Robbins, M., 2010, 'Internal consistency reliability of the Estonian translation of the Oxford Happiness measure: Contributing to positive Estonian translation of the Oxford Happiness measure: Contributing to positive
psychology in Estonia', in E.E. Wells (ed.), Psychological wellbeing, pp. 223-230, Nova Science Publishers, New York, NY.

Fisher, J.W., 2004, 'Feeling good, living life: A spiritual health measure for young children', Journal of Beliefs and Values 25(3), 307-315. https://doi.org/ 10.1080/1361767042000306121

Fisher, J.W., 2010, ‘Development and application of a spiritual well-being questionnaire called SHALOM', Religions 1(1), 105-121. https://doi.org/10.3390/rel1010105

Fisher, J.W., 2011, 'The Four Domains Model: Connecting spirituality, health and well-being', Religions 2(1), 17-28. https://doi.org/10.3390/rel2010017

Fisher, J.W., 2016, 'Selecting the best version of SHALOM to assess spiritual wellbeing', Religions 7(5), 45. https://doi.org/10.3390/rel7050045

Fisher, J.W., 2021, 'Validation and utilisation of the spiritual wellbeing questionnaire: SHALOM', Journal of Religion and Health 60, 3694-3715.

Francis, L.J., 1990, 'Theology of education', British Journal of Educational Studies 38(4), 349-364. https://doi.org/10.1080/00071005.1990.9973862

Francis, L.J. (ed.), 2015, Anglican cathedrals in modern life: The science of cathedral studies, Palgrave Macmillan, New York, NY.

Francis, L.J., 2005, Faith and psychology: Personality, religion and the individual, Darton, Longman and Todd, London.

Francis, L.J., Edwards, O.D. \& ap Siôn, T., 2021, 'Applying psychological type and psychological temperament theory to the congregations at cathedral carol services', Mental Health, Religion and Culture 24(4), 412-424. https://doi.org/10. 1080/13674676.2020.1764516

Francis, L.J. \& Jones, S.H., 2020, 'Cathedrals as agents of wellbeing within secular societies: Assessing the impact of the Holly Bough service in Liverpool Cathedral', HTS Teologiese Studies / Theological Studies 76(3), a6250. https://doi.org/10.4102/ hts.v76i3.6250

Francis, L.J., Jones, S.H., McKenna, U., Pike, N. \& Williams, E., 2020, 'The science of cathedral studies: Exploring the demographic profile, motivational intentions, and perceived impact on spiritual wellbeing among those attending the Holly Bough Service in Liverpool Cathedral', Religions 11(9), 478. https://doi.org/10.3390/rel11090478

Francis, L.J., Jones, S.H. \& Wilcox, C., 2000, 'Religiosity and happiness: During adolescence, young adulthood and later life', Journal of Psychology and Christianity 19, 245-257. 
Francis, L.J. \& Katz, Y., 2000, 'The internal consistency reliability and validity of the Hebrew translation of the Oxford Happiness Inventory', Psychological Reports 87 193-196. https://doi.org/10.2466/pr0.2000.87.1.19

Francis, L.J. \& Katz, Y.J., 2002, 'Religiosity and happiness: A study among Israeli female undergraduates', Research in the Social Scientific Study of Religion 13, 75-86.

Francis, L.J., Katz, Y.J., Yablon, Y. \& Robbins, M., 2004, 'Religiosity, personality and happiness: A study among Israeli male undergraduates', Journal of Happines Studies 5, 315-333. https://doi.org/10.1023/B:JOHS.0000048460.35705.e8

Francis, L.J. \& Lester, D., 1997, 'Religion, personality and happiness', Journal of Contemporary Religion 12(1), 81-86. https://doi.org/10.1080/13537909708580791

Francis, L.J. \& Lewis, C.A., 2016, 'Personal happiness and religious affect: An empirical enquiry among 16- to 19-year-old students in the Republic of Ireland', Spirituality of a Personality 3(72), 98-116.

Francis, L.J., Ok, U. \& Robbins, M., 2017, 'Religion and happiness: A study among university students in Turkey', Journal of Religion and Health 56, 1335-1347. https://doi.org/10.1007/s10943-016-0189-8

Francis, L.J. \& Robbins, M., 2000, 'Religion and happiness: A study in empirical theology', Transpersonal Psychology Review 4, 17-22.

Francis, L.J., Robbins, M. \& White, A., 2003, 'Correlation between religion and happiness: A replication', Psychological Reports 92(1), 51-52. https://doi. org/10.2466/pro.2003.92.1.5

Francis, L.J., Yablon, Y.B. \& Robbins, M., 2014, 'Religion and happiness: A study among female undergraduate students in Israel', International Journal of Jewish Education Research 7, 77-92.

Furnham, A. \& Cheng, H., 1999, 'Personality as predictors of mental health and happiness in the East and West', Personality and Individual Differences 27(3), 395-403. https://doi.org/10.1016/S0191-8869(98)00250-5

Gallagher, M.W. \& Lopez, S.J., 2019, Positive psychological assessment: A handbook of models and measures, 2nd edn., America Psychological Association, Washington, DC.

Hills, P. \& Argyle, M., 2002, 'The Oxford Happiness Questionnaire: A compact scale for the measurement of psychological well-being', Personality and Individual Differences 33(7), 1073-1082. https://doi.org/10.1016/S0191-8869(01)00213-6

Janssen, F. \& Bänziger, S., Dezutter, J. \& Hutsebaut, D., 2006, 'Religion and mental health: Aspects of the relation between religious measures and positive and negative mental health', Archive for the Psychology of Religion 27(1), 19-44. https://doi.org/10.1163/008467206774355402

Kashdan, T.B., 2004, 'The assessment of subjective well-being (issues raised by the Oxford Happiness Questionnaire)', Personality and Individual Differences 36(5), 1225-1232. https://doi.org/10.1016/S0191-8869(03)00213-7

Kennerley, P., 2008, The building of Liverpool Cathedral, 3rd revised edn., Carnegie Publishing, Lancaster.

Lewis, C.A., Francis, L.J. \& Ziebertz, H.-G., 2002, 'The internal consistency reliability and construct validity of the German translation of the Oxford Happiness Inventory', North American Journal of Psychology 4, 211-220.

Lu, L., Shih, J.B., Lin, Y.Y. \& Ju, L.S., 1997, 'Personal and environmental correlates of happiness', Personality and Individual Differences 23(3), 453-462. https://doi. org/10.1016/S0191-8869(97)80011-6

Lyubomirsky, S., Sheldon, K.M. \& Schkade, D., 2005, 'Pursuing happiness: The architecture of sustainable change', Review of General Psychology 9(2), 111-131. architecture of sustainable change, Review
https://doi.org/10.1037/1089-2680.9.2.111

Meleddu, M., Guicciardi, M., Scalas, L.F. \& Fadda, D., 2012, 'Validation of an Italian version of the Oxford Happiness Inventory in adolescents', Journal of Personality Assessment 94(2), 175-185. https://doi.org/10.1080/00223891.2011.645931

Murphy, J., 1971, Church, state and schools in Britain 1800-1970, Routledge and Kegan Paul, London.

Murphy, L., 2016, 'The nostalgia of Christmas worship: A resource for re-collection re-flection and re-newal, as experienced at the Christmas Eve Carol service held at Holy Trinity Church, Stratford upon Avon in 2015', Unpublished MA dissertation, Heythrop College, University of London.
Muskett, J.A., 2017, 'The greater church as "sacred space, common ground": A narrative case study within a rural diocese', Rural Theology 15(1), 22-38. https:// doi.org/10.1080/14704994.2017.1298227

Neto, F., 2001, 'Personality predictors of happiness', Psychological Reports 88(3), 817-824. https://doi.org/10.2466/pr0.2001.88.3.817

Phillips, R., 2010, 'Christmas is not just for Christmas: An exploration of the Christmas story and its meaning as told by members of the congregation at the Festival of Nine Lessons and Carols held at York Minster on Christmas Eve 2007', Unpublished MPhil dissertation, University of Nottingham.

Pike, N.A., 2021, 'The Holly Bough Service at Liverpool Cathedral: A location and occasion for encounter?', Journal of Beliefs and Values. https://doi.org/10.1080/1 3617672.2021.1914914

Robbins, M. \& Francis, L.J., 1996, 'Are religious people happier? A study among undergraduates', in L. Francis, W.K. Kay \& W.S. Campbell (eds.), Research in religious education, pp. 207-217, Gracewing, Leominster.

Rumsey, A., 2017, Parish: An Anglican theology of place, SCM Press, London.

Ryan, R.M. \& Deci, E.L., 2001, 'On happiness and human potentials: A review of research on hedonic and eudaimonic well-being', Annual Review of Psychology 52(1), 141-166. https://doi.org/10.1146/annurev.psych.52.1.141

Seligman, M., 2002, Authentic happiness: Using the new positive psychology to realise your potential for lasting fulfilment, Nicholas Brealey, London.

Tekke, M., Francis, L.J. \& Robbins, M., 2018, 'Religious affect and personal happiness: A replication among Sunni students in Malaysia', Journal of Muslim Mental Health 11(2), 3-15. https://doi.org/10.3998/jmmh.10381607.0011.201

Thomas, J., 2018, Liverpool Cathedral: Themes and forms in a great modern church building, Twin Books, Wolverhampton.

Tiliopoulos, N., Francis, L.J. \& Slattery, M., 2011, 'The affective dimension of religion and happiness among Hindu Bunts in South India', Transpersonal Psychology Review 14, 25-29.

Walker, D.S., 2012a, 'Attending the service of nine lessons and Carols in a rural cathedral: An empirical study in religious orientation and motivational style', Rural Theology 10(1), 56-69. https://doi.org/10.1558/ruth.v10i1.56

Walker, D.S., 2012b, 'O Come all ye thinking types: The wider appeal of the cathedral carol service', Mental Health, Religion and Culture 15, 987-995. https://doi.org/1 $0.1080 / 13674676.2012 .707436$

Walker, D.S., 2013, 'How far is it to Bethlehem? Exploring the ordinary theology of occasional churchgoers', in J. Astley \& L.J. Francis (eds.), Exploring ordinary theology: Everyday Christian believing and the church, pp. 137-145, Ashgate, Farnham.

Walker, D.S., 2014, 'The inclusivity of Rural Anglicanism: Theoretical and empirical considerations', PhD dissertation, University of Warwick.

Walker D.S., 2015a, 'Cathedral carol services: Who attends and why', in L.J. Francis (ed.), Anglican cathedrals in modern life: The science of cathedral studies, pp. 111-129, Palgrave Macmillan, New York, NY.

Walker, D.S., 2015b, 'Unsettling the guardian: Quest religiosity and psychological type among Anglican churchgoers', Mental Health, Religion and Culture 18(8), 655-663. https://doi.org/10.1080/13674676.2014.963291

Williams, E., Francis, L.J., Robbins, M. \& Annis, J., 2007, 'Visitor experiences of St Davids Cathedral: The two worlds of pilgrims and secular tourists', Rural Theology 5(2), 111-123. https://doi.org/10.1179/rut_2007_5_2_004

Winter, M. \& Gasson, R., 1996, 'Pilgrimage and tourism: Cathedral visiting in contemporary England', International Journal of Heritage Studies 2(3), 172-182. https://doi.org/10.1080/13527259608722170

Ysseldyk, R., Haslam, S.A. \& Morton, T.A., 2016, 'Stairway to heaven? (Ir)religious identity moderates the effects of immersion in religious spaces on self-esteem and self-perceived physical health', Journal of Environmental Psychology 47 14-21. https://doi.org/10.1016/j.jenvp.2016.04.016 